\title{
Searching for Truth But Missing the Point
}

\author{
KEITH D. KILBACK ` AND MiChaEl D. TOCHOR *
}

This article explores the shift from the traditional conceptualization of a criminal trial as an independent testing of facts to the standard of proof beyond a reasonable doubt, to a more recent view of the trial as a search for the truth.

The authors contend that the "search for truth" approach imports two major flaws into the judicial process. First, it is impossible for a trier of fact 10 actually know the truth; and second, because the concept has never been judicially defined, its use allows courts to justify whatever policy decision is being made.

The authors conclude that the traditional view remains the better view, because the fundamental point of a criminal trial is not to determine what is true, but rather to determine whether the accused is guilty beyond a reasonable doubt.
Cet article explore le glissement du concept traditionnel du procès criminel comme un test indépendant des faits visant lëtablissement de la preuve hors de tout doute raisonnable, vers une perception récente du procès comme une recherche de la vérité.

Les auteurs affirment que l'approche de la "recherche de la vérité" insère deux failles majeures dans le processus judiciaire. Premièrement, il est impossible à un juge des faits de connaitre avec certitude la vérité et. deuxièmement, le concept n'ayant jamais été défini de manière judiciaire, son utilisation permet aux cours de justifier la prise de n'importe quelle décision politique.

Les auteurs concluent que le point de vue traditionnel demeure le meilleur parce que le but fondamental d'un procès criminel n'est pas de déterminer la vérité. mais plutöt si l'accusé est coupable hors de tout doute raisonnable.

\section{TABLE OF CONTENTS}

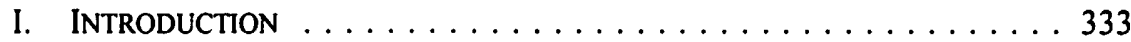

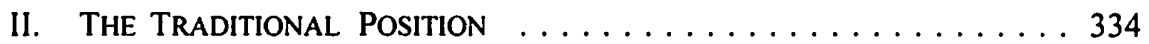

III. RECENT JURISPRUDENCE $\ldots \ldots \ldots \ldots \ldots \ldots \ldots \ldots \ldots \ldots$

IV. FACTS ARE GUESSES $\ldots \ldots \ldots \ldots \ldots \ldots \ldots \ldots \ldots \ldots \ldots \ldots \ldots \ldots$

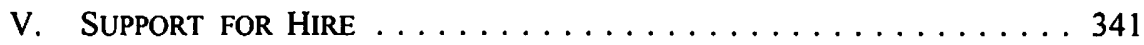

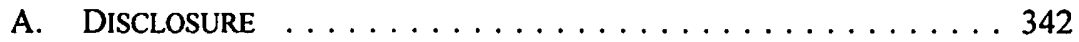

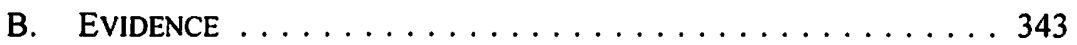

VI. Conclusion $\ldots \ldots \ldots \ldots \ldots \ldots \ldots \ldots \ldots \ldots \ldots \ldots \ldots \ldots \ldots \ldots \ldots$

There is no "true." There are merely different ways of perceiving truth.

- Flaubert

\section{INTRODUCTION}

In recent years and with increasing frequency, the Supreme Court of Canada has referred to a criminal trial as being a search for the truth. The conceptualization of a criminal trial as a search for truth is a shift from older jurisprudence that sees the criminal trial process as an independent testing of facts to the required legal standard

- Kanuka Thuringer, Regina, Saskatchewan.

-• MacPherson Leslie \& Tyerman LLP, Regina, Saskatchewan. 
in order to determine if facts have been proven beyond a reasonable doubt. In a series of pithy and sometimes casual references, the Supreme Court has presented this notion as a "given" in Canadian jurisprudence. Closer examination of the role of truth seeking in the criminal trial process reveals that such a view was not always so readily accepted, and that the recent introduction of this idea is perhaps not well-founded.

Two main criticisms of the view that a criminal trial is a search for truth can be offered. First, at a fundamental level, it is impossible for a trier of fact to know the truth. At best, a trial judge accepts facts as proven based on the evidence presented, but judges cannot know for certain whether those facts are true, in the literal sense of the word.

Second, the Supreme Court appears to be using the idea to lend support to philosophically diverse policy decisions by simply stating that those decisions are necessary in order to advance the "search for truth." By using the phrase as if it were a long-standing fundamental tenet of Canadian legal theory without embarking on a critical examination of what it means, the Supreme Court has used the "truth seeking" function of the court as a convenient way to support desired outcomes depending on the circumstances of the particular case under review, instead of adopting a principled approach to the concept.

Seeing a criminal trial as a search for truth undeniably has a certain appeal. Such a view evokes images of the judge as a righteous figure dedicated to ensuring that truth prevails. The problem is that truth has very little to do with the point of a criminal trial.

\section{The Traditional Position}

Traditionally, the role of a judge presiding over a criminal trial was to act as an umpire, to enforce the rules, and to declare a winner. This approach is bluntly articulated in Thompson v. Glasgow Corporation:

\footnotetext{
Judges sometimes flatter themselves by thinking that their function is the ascertainment of truth.... A litigation is in essence a trial of skill between opposing parties conducted under recognized rules, and the prize is the judge's decision. We have rejected inquisitorial methods and prefer to regard our judges as entirely independent. Like referees at boxing contests they see that the rules are kept and count the points.
}

This view recognizes a healthy respect for the limitations that human beings have in assessing one another. The court in R. v. M.E.M. ${ }^{2}$ illustrates this point:

I (1961) Scots Law Times 237 at 245-46. In Phillips v. Ford Motor Co. of Canada Lid., [1971] 2 O.R. 637 (C.A.), Evans J.A. wrote at 657: "Undoubtedly a Court must be concerned with truth, in the sense that it accepts as true certain sworn evidence and rejects other testimony as unworthy of belief, but it cannot embark upon a quest for the 'scientific' or 'technological' truth when such an adventure does violence to the primary function of the Court, which has always been to do justice, according to law."

[1998] N.W.T.J. No. 50 (S.C.), online: QL (NWTJ). 
Many judges have often said that the law does not clothe a judge with divine insight into the hearts and minds of witnesses. We cannot profess to be able to determine absolute truth. All we can do is apply time-honoured means to determine whether an allegation has been proven to the standard that is the only one acceptable in criminal law, that being beyond a reasonable doubt.

On a philosophical and practical level a trial should be a search for the truth. But judges are not detectives, they are judges. And what they must judge are not the individuals but the evidence. ${ }^{3}$

The traditional view is that a criminal trial is a systematic testing of evidence to the requisite legal standard, rather than a chase for elusive notions of truth. This view is being subtly replaced by the idea that a criminal trial is instead a search for the truth, and it is interesting to review how this shift has occurred.

\section{RECENT JURISPRUDENCE}

\section{In $R$. v. $A \cdot G .^{4}$ the Supreme Court of Canada said:}

This Court has repeatedly held that myths and stereotypes have no place in a rational and just system of law, as they jeopardize the courts' truth-finding function. (See R.v. Seaboyer, [1991] 2 S.C.R. 577, at pp. 604 and 630, per McLachlin J., and at p. 651, per L'Heureux-Dubé J. dissenting in part; $R$. $v$. Osolin, [1993] 4 S.C.R. 595, at p. 670, per Cory J.; R. v. Esau, [1997] 2 S.C.R. 777, at para. 82, per McLachlin J.; R. v. S.(R.D.), [1997] 3 S.C.R. 484, at para. 29, per L'Heureux-Dubé and McLachlin JJ.; R. v. Ewanchuk, [1999] I S.C.R. 330, at paras. 91-99, per L'Heureux-Dubé J.; R. v. W.(G.), [1999] 3 S.C.R. 597, at para. 29, per L'Heureux-Dubé J.) ${ }^{5}$

Curiously, none of the references cited refer to the Court's truth finding function. In each of those passages the Court discusses the role of myths and stereotypes, but does not mention the role of truth finding. ${ }^{6}$ The truth-finding function of the Court is simply

Ibid. at 1 .

[2000] I S.C.R. 439, 143 C.C.C. (3d) 46 [cited to S.C.R.].

Ibid. at 443 , para. 2.

A review of each of the cited passages is interesting. The following are excerpts from the cited paragraphs:

$R$ v. Seaboyer: "These inferences were based not on facts, but on the myths that unchaste women were more likely to consent to intercourse and in any event, were less worthy of belief. These twin myths are now discredited."

$R$. v. Osolin: "The reasons in Seaboyer make it clear that eliciting evidence from a complainant for the purpose of encouraging inferences pertaining to consent or the credibility of rape victims which are based on groundless myths and fantasized stereotypes is improper."

$R$. v. Esau: "Care must be taken to avoid the false assumptions or 'myths' that may mislead us in determining whether the conduct of the complainant affords a sufficient basis for putting the defence of honest mistake on consent to the jury. One of these is the stereotypical notion that women who resist or say no may in fact be consenting."

$R$. v. S.(R.D.): "[W]hile judges can never be neutral, in the sense of purely objective, they can and must strive for impartiality. It therefore recognizes as inevitable and appropriate that the differing experiences of judges assist them in their decision making process and will be reflected in their judgments, so long as those experiences are relevant to the cases, are not based on inappropriate stereotypes, and do not prevent a fair and just determination of the cases based on the facts in evidence." 
stated as a fact.

One of the most frequently cited references to the search for truth in recent years is found in $R$. v. Nikolovski, ${ }^{7}$ in which the Supreme Court of Canada states:

The ultimate aim of any trial, criminal or civil, must be to seek and to ascertain the truth. In a criminal trial the search for truth is undertaken to determine whether the accused before the court is, beyond a reasonable doubt, guilty of the crime with which he is charged. ${ }^{8}$

It is noteworthy that the Supreme Court does not provide any analysis of the concept, but simply states it as a fact. A similar statement was made by the Alberta Court of Queen's Bench in R. v. B.S.G., in which the Court states that "a criminal trial is a search for the truth [that] ultimately boils down to whether or not the Crown is able to meet its burden of establishing the guilt of the accused beyond a reasonable doubt."

Some insight into the genesis of this idea may be found in $R$. v. G.(B.), ${ }^{11}$ in which the Court discusses the proper interpretation of s. 672.21 of the Criminal Code, a section dealing with the circumstances in which a "protected statement" made by an accused to a psychiatrist who is assessing his or her fitness to stand trial is admissible. ${ }^{12}$ The Court states that in enacting the section Parliament was concerned with achieving a balance between the need to learn the truth (what the court called the "essential principle" of every criminal trial), and the protection of accused persons ordered to undergo an assessment of their mental capacity. In support of this comment, the Court quotes from a speech in the House of Commons given by the Minister of Justice at the time, the Honourable Kim Campbell, in which Campbell referred to the

$R$ v. Ewanchuk: "This would mean that complying to receive a massage is consent to sexual touching. It would reflect the myth that women are presumptively sexually accessible until they resist."

R. v. W.(G.): "[S]uch comments may be perceived as reflecting myths and stereotypes about complainants in sexual assault cases."

In one other case that is not cited, $R$. v. Marquard, [1993] 4 S.C.R. 223, the Supreme Court does draw a link between assumptions about human behaviour and the search for truth in the context of allowing expert testimony in child abuse cases. The Cour writes at para. 94 that "if the trial process is a search for the truth, then misplaced assumptions about human behaviour which drive the trier of fact to draw incorrect inferences from the evidence must be unmasked if this process is not to be subverted rather than furthered." (1996), 111 C.C.C. (3d) 403 (S.C.C.), rev'g 92 C.C.C. (3d) 37 (Ont. C.A.) [hereinafter Nikolovski cited to C.C.C.].

Ibid. at 409. This passage has been cited with approval by trial judges in $R$. v. Penney, [1999] N.J. No. 269 (Prov. Ct.), online: QL (NJ); and $R$. v. Smarden, [2000] N.S.J. No. 59 (Prov. Ct.), online: QL (NSJ).

[1999] A.J. No. 257, online: QL (AJ) [hereinafter B.S.G.].

lbid. at para 155 .

[1999] 2 S.C.R. 475, 135 C.C.C. (3d) 303, aff'g (1997), 119 C.C.C. (3d) 276 (Que. C.A.) [cited to S.C.R.].

R.S.C. 1985 , c. C-46. 
need for prosecutors to be able to use such statements as substantive evidence in order to "learn the truth about the accused and the offence." 13

Although the idea that the search for truth is an "essential principle" of every criminal trial may have developed as an extension of perceived legislative intention, the concept has not been the subject of critical analysis by the Supreme Court. Since there has not been a measured, judicial consideration of what it means to say that a criminal trial is a "search for truth," the phrase is difficult to interpret.

The tacit contradiction implicit in the passages in Nikolovski and B.S.G. illustrates the problem in using the phrase. The Court in Nikolovski states that "the search for truth is undertaken to determine whether the accused before the court is, beyond a reasonable doubt, guilty of the crime," but this cannot be the case. ${ }^{14}$ A criminal trial must be either a search for truth or a systematic testing and evaluation of the evidence presented. It cannot be both, since the court's focus is different depending upon the philosophical viewpoint adopted.

If judges are concerned with finding the empirical "truth" about what took place, and if that is the focus of the exercise, then evidentiary issues take on less importance and technical objections to the admissibility of evidence must be outweighed by the judge's "ultimate aim"15 of finding the truth. On the other hand, if judges are evaluating the evidence with a view to determining whether certain facts have been proven beyond a reasonable doubt, then evidentiary issues are very important. A court is either looking for the truth or is looking to find proof beyond a reasonable doubt.

This concept has been quietly introduced into Canadian law without any real indication of what it means. Without judicial guidance on this point, two main criticisms of the view that a criminal trial is a search for truth can be offered. First, it is impossible for a trier of fact to know the truth, and as such the premise of the concept is not well-founded. Second, rather than adopting a principled approach to the concept, courts are using the phrase as a convenient way to support desired outcomes on philosophically diverse policy decisions by simply stating that those decisions are necessary in order to advance the "search for truth."

$R$ v. G.(B.), supra note 11 at para 38 :

In a speech in the House of Commons on October 4, 1991 (during second reading of the bill), the then Minister of Justice, the Honourable Kim Campbell. identified the interests the legislation was seeking to reconcile. She said ... "At the same time, concern has been expressed by prosecutors that completely prohibiting the use of this evidence would deprive the court of important information needed to learn the truth about the accused and the offence." (House of Commons Debates, vol. III, 3rd sess., 34th Parl., at p. 3296.). Parliament thus sought a balance between the need to learn the truth and the protection of accused persons ordered to undergo an assessment of their mental capacity.

For a survey of this and other recent cases in which the Supreme Court of Canada has used parliamentary debates as an aid in statutory interpretation, see S. Beaulac, "Recent Developments at the Supreme Court of Canada on the Use of Parliamentary Debates" (2000) 63 Sask. L. Rev. 581. 


\section{FACTS ARE GUESSES ${ }^{16}$}

The first criticism of this concept is that it is simply impossible for a trier of fact to know the truth. Such language presupposes that judges have a particular ability or skill in determining whether witnesses are lying or telling the truth. After all, if a criminal trial is indeed a search for truth, then judges must be able to identify the liars. If not, how could truth be found?

In an oft-cited passage, O'Halloran J.A. states that "the law does not clothe the trial judge with a divine insight into the hearts and minds of the witnesses." 17 Judges have historically been very cognizant of their limitations in assessing credibility and considering the demeanour of a witness. Some, like Lord Devlin, take pains to point out that judges do not have a divine insight. ${ }^{18}$ Marcus Stone has echoed this sentiment:

The complexity of responses and the differences between individuals are such that, in isolation, so far as lying is concerned, anything about a particular witness's behaviour, may mean anything. The conclusion must be that it is only proper for observation of a witness's demeanour to play a minor role in lie detection. Alone, it is an unsound basis for deciding whether or not he is lying, and it should never be the ground of conviction. ${ }^{19}$

In a relatively obscure, yet engaging work, the American appellate judge Jerome Frank has posited that judicial findings of fact are nothing more than mere guesses. ${ }^{20}$ Although published in 1950, this work embodies concepts that have been empirically proven a generation or more later.

Judge Frank's basic thesis is that human judges are fallible, and cannot do any better than guess at the competing versions of facts that they have before them in any given lawsuit. On a theoretical level, a lawsuit is very simple: applying a legal rule to a particular set of facts. However, determining the facts is at best only what the trial judge "thinks happened"; a judge's opinion may still be "hopelessly incorrect." 21

In a manner prescient of future studies, Frank J. notes three categories where eyewitness testimony could be prone to error. First, the witness could "have erroneously

This heading is taken from chapter 3 of J. Frank, Courts on Trial: Myth and Reality in American Justice (Princeton: Princeton University Press, 1950).

17 Farnya v. Chorney (1951-52), 4 W.W.R. (N.S.) 171 at 175 (B.C. C.A.).

14 Lord P. Devlin, The Judge (Oxford: Oxford University Press, 1979) at 63: "The great virtue of the English trial is usually said to be the opportunity it gives to the judge to tell from the demeanour of the witness whether or not he is telling the truth. I think that this is overrated." Lord Devlin later adopted the views of McKenna J. at 63: "I doubt my own ability ... to discern from a witness's demeanour, or the tone of his voice, whether he is telling the truth.... For my part 1 rely on these considerations as little as I can help."

19) M. Stone, Cross-examination in Criminal Trials (London: Butterworths, 1988) at 61.

20 Frank, supra note 16.

"I Ibid. at 15: "At best, it is only what the trial court - the trial judge or jury - thinks happened. What the trial court thinks happened may, however, be hopelessly incorrect. But that does not matter - legally speaking. For court purposes, what the court thinks about the facts is all that matters." 
observed [a] past event at the time it occurred."22 Second, the witness may "erroneously remember" the observation. ${ }^{23}$ Third, the witness could "inaccurately report" his story. ${ }^{24}$ Surprisingly, these categories dovetail with later research completed by Elizabeth Loftus, a prominent American psychologist who has conducted extensive research in the area of eyewitness testimony. ${ }^{25}$

Judge Frank's first stage - the observation stage - parallels the acquisition stage defined by Loftus. She notes that there are a variety of factors that can dramatically affect a witness's ability to perceive an event accurately. ${ }^{26}$ The ability to perceive an event will be affected by event factors, such as exposure time or detail salience ${ }^{27}$ as well as witness factors, which include stress, expectations, and potential biases. ${ }^{28}$ Thus, a variety of influences can determine how a person actually perceives events that are unfolding before him or her.

Judge Frank's second stage - the retaining of information - again parallels a retention stage set out by Loftus. As Frank J. notes, even if a witness accurately observes an event, he may nevertheless "erroneously remember" that observation. ${ }^{29}$ Loftus points out that during the time between an event and a witness's recollection of that event - a period often called the "retention interval" - the bits and pieces of information that were acquired through perception do not passively reside in memory waiting to be pulled out like fish from water. Rather, they are subjected to numerous influences. External information can intrude into the witness's memory, as can his or her own thoughts, and both can cause dramatic changes in his recollection. ${ }^{30}$

Ibid. at 17: "The witness may erroneously have observed the past event at the time it occurred. The rankest amateur in psychology knows how faulty observation is, knows that what a man thinks he observes may not accord with what actually happened. Human observation is obviously fallible, subjective. It is affected by defects of sight, or hearing, or by the observer's emotional state or physiological condition and by his preconceived notions. 'Men,' say the courts, 'often think they see what they did not see, ... misinterpret what they hear.' As hundreds of experiments have demonstrated, two observers of the same happening frequently disagree."

23. Ibid:: "But suppose a witness made no error in his original observation of an event. He may, nevertheless, erroneously remember that correct observation. The faulty, subjective, nature of human memory is notorious. Many a witness has an imaginative memory."

24 Jbid. at 18: "Now we come to the stage where the witness reports in the court-room his present recollection of his original observation. Here, again, error may enter. The honest witness, due to a variety of causes ... may inaccurately report his story."

25 See E. Loftus, Eyewitness Testimony (Cambridge: Harvard University Press, 1979). See also E. Loftus, Memory: Surprising New Insights Into How We Remember and Why We Forget (London: Addison Wesley, 1980).

26. Ibid. (1979) at 50-51: "In the acquisition stage, there are numerous factors that will affect the accuracy of the initial perception. Some of these factors, such as the amount of time the witness had to look at whatever is going to be remembered, are inherent in the situation itself. Other factors, such as the amount of stress a witness is experiencing, are inherent in the witness." Jbid. at 23-25; at 25: "When a complex incident is witnessed, not all of the details within that incident are equally salient, or memorable, to the witness. Some things just catch our attention more readily than others. A salient detail is one that has a high probability of being spontaneously mentioned by individuals who witness a particular event." 
Judge Frank's third stage - inaccurate reporting - parallels the retrieval stage enunciated by Loftus. At this stage, errors may occur when a witness reports an observed event. Loftus describes some of the more important factors that operate during this stage, such as the types of questions that are used to obtain information, how these questions are worded, and who is asking them. She notes that "the line between valid retrieval and unconscious fabrication" is easily crossed. ${ }^{31}$

In her testimony before the Sophonow Inquiry, Loftus elaborated on these different influences in the retrieval stage. ${ }^{32}$ She indicated that repeated information retrieval, or repeating a particular recollection, can make a person more confident in that recollection. However, the additional confidence does not come from greater accuracy in the recollection, but rather comes from repetition of the recollection. Thus, in some instances, "even guesses [can] turn into highly confident memories." 33

It is very difficult for the objective truth to be made visible after proceeding through the three filters of acquisition, retention and retrieval. Inaccuracies at any one of the stages will distort reception; inaccuracies in two or three could, in some circumstances, render accuracy unattainable.

Judge Frank also adds a further filter to the truth-finding process when he points out that judges suffer from the same weaknesses as the witnesses testifying before the Court. He notes that the reaction of a trial judge to a witness is "shot through with subjectivity," ${ }^{34}$ and that a trial court's findings are, at best, a belief or opinion about someone else's belief or opinion. It is, as Frank J. states, "subjectivity piled on subjectivity." ${ }^{35}$

This potential for inaccuracy applies even assuming that a witness is doing his or her utmost to be accurate. It does not, however, take into account a witness who may be lying. And, once again, there may be those who know they are lying and those who, although initially lying, convince themselves they are telling the truth. In a paper presented at an American Psychological Society Conference, it was noted that people who repeatedly lie about an event may come to believe their version of the event. These

Ibid. at 108-109.

Testimony of E. Loftus, Sophonow Inquiry before Commissioner Cory, Winnipeg, Manitoba, (12 May 2000) as reported in A. Gold's Netletter, ADGN/RP-115, online: QL (GOLD).

Ibid. at 10. Loftus pointed out at page nine of the transcript that the relationship between confidence and accuracy is a relatively weak one. She also pointed out that when the confidence of a witness is strong, due to feedback or repeated recollections, it is very hard to adequately cross-examine. See also J. Brean, "Researchers Create False Memories With Greatest of Ease" National Post (13 June 2001) Al. A study was conducted by Loftus at the University of Washington in which up to 40 percent of subjects reported that they remembered meeting Bugs Bunny at Disneyland, although Bugs is a Warner Bros. character and would never appear at the Disneyland theme park.

Frank, supra note 16 at 22: "The facts as they actually happened are therefore twice refracted first by the witnesses, and second by those who must 'find' the facts. The reactions of trial judges or juries to the testimony are shot through with subjectivity."

Ibid. 
people will not then display any of the body or facial movements that can betray a liar. $^{36}$

Paul Ekman, a noted expert in evaluating clues to deceit, has found that judges and trial attorneys (among others) can do no better than chance in assessing whether people lie. Further, and equally astonishing, he found that most of them did not even know that "they could not detect deceit from demeanour." 37

Therefore, facts are nothing more than guesses. Indeed, in some instances, one may suggest that the collision between testimony and truth is nothing more than an accident. Perhaps the most that can be hoped for is described in Rex. v. Pressley, where the Court observed that " $[t]$ he utmost result that can ... be produced by judicial evidence is a very high degree of probability" that a witness is telling the truth when he or she affirms the existence of a fact. ${ }^{38}$ In a recent article, Judge Gerald Seniuk writes:

\begin{abstract}
We are more aware now that the trier of fact "does not ascertain the truth in any real sense. What he does is to give a decision on the evidence presented to him, evidence which is often incomplete, and with the collection and presentation of which the judge himself has nothing to do." The problem is made even more intractable because it is not simply a problem of ignorance, of not having all the facts, but emerges from the dynamics of human reasoning, which in part is a product of one's personal experience, one's "cognitive filters." 39
\end{abstract}

\title{
V. SUPPORT FOR HIRE
}

A second criticism of the view that a criminal trial is a search for truth relates to the seemingly arbitrary way that the phrase is invoked by judges to lend philosophical justification to whatever policy decision is being made. Put simply, because it has not

36 C. Norton, "American Psychological Society Conference: Study Uncovers the Truth About Lying" The Independent (5 June 1999) 7. The paper in question was presented by D. Polage of the University of Washington at the American Psychological Society annual conference in Denver, Colorado in 1999.

37 P. Ekman, Telling Lies (New York: W.W. Norton, 1992) at 285: "It is amazing to many people when they learn that all of the other professional groups concerned with lying - judges, trial attorneys, police, polygraphers who work for the CIA, FBI or NSA (National Security Agency), the military services, and psychiatrists who do forensic work - did no better than chance. Equally astonishing, most of them did not know they could not detect deceit from demeanour." In Ekman's testing, only one group, the American Secret Service, did better than chance.

38 (1948), 94 C.C.C. 29 at 33-34 (B.C. C.A.): "In 'General View of the Criminal Law', 1890, Mr. Justice Stephen said at p. 191: 'The utmost result that can in any case be produced by judicial evidence is a very high degree of probability... The highest probability at which a court of justice can, under ordinary circumstances, arrive is the probability that a witness or set of witnesses tell the truth when they affirm the existence of a fact.... But probability of this kind is not the product of arbitrary decision. It is founded upon a rational review of the evidence step by step, wherein the balance is reached under conditions which push suspicion, preconceived notions, conjecture and guessing into the background." See also C.H. O'Halloran. "Problems in the Modern Appeal in Civil Cases" (1949) 27 Can. Bar Rev. 258 at 273.

39 G.T.G. Seniuk, "Liars, Scoundrels and the Search for Truth" (2000) 30 C.R. (5th) 244 at 250-51 [footnotes omitted]. 
been clearly defined or articulated, the concept is available to support almost any position as being necessary in order to advance the search for truth.

From the perspective of an accused there are two main areas where this is apparent. First, it is used in the context of disclosure as a justification to both allow and restrict an accused's access to information. Second, it is used as a justification to both limit evidentiary and procedural protections that are available to an accused, and to protect an accused from unfaimess at trial.

\section{A. Disclosure}

Consider the context of an accused seeking access to therapeutic records of a complainant in a sexual assault case. In the leading case, $R$. v. Mills, ${ }^{40}$ the Court considers this issue and makes the following comments:

From our preceding discussion of the right to make full answer and defence, it is clear that the accused will have no right to the records in question insofar as they contain information that is either irrelevant or would serve to distort the search for truth, as access to such information is not included within the ambit of the accused's right. ${ }^{41}$

The court went on to hold that "the right to full answer and defence is not engaged where the accused seeks information that [would] only serve to distort the truth-seeking purpose of a trial." ${ }^{42}$

The Supreme Court has clearly indicated that the privacy rights of complainants outweigh an accused's right to make full answer and defence in this situation, based in part on the need to ensure that the search for truth is not "distorted" by an accused. ${ }^{43}$ The search for truth is used as a justification for limiting an accused's access to information.

The concept is also concurrently being cited as a justification in favour of the disclosure of information to an accused. In $R$. v. Stinchcombe, ${ }^{44}$ Sopinka J. commented that "the search for truth is advanced rather than retarded by disclosure of all relevant material." ${ }^{45}$ Similarly, in $R$. v. Schmidt, ${ }^{46}$ the Court noted that "[i]f the system of

[1999] 3 S.C.R. 668,139 C.C.C. (3d) 321 [cited to S.C.R.].

lbid. at 726 , para. 89.

Ibid. at 729, para. 94.

The search for truth is used in the same way in $R$. v. Batte (2000), 145 C.C.C. (3d) 449 (Ont. C.A.); $R$. v. Shearing (2000), 143 C.C.C. (3d) 233 (B.C. C.A.); R. v. W.G., [2000] N.J. No. 86 (S.C. (T.D.)), online: QL (NJ); and in R. v. Hunter (2000), 268 A.R. 90 (Prov. Ct. (Crim. Div.)). (1991), 68 C.C.C. (3d) 1 (S.C.C.).

Ibid. at 8. This sentiment was echoed by the Supreme Court in $R$. v. La (appeal by Vu), [1997] 2 S.C.R. 680 at 699: "At the outset, however, I would stress that disclosure, as a process, is a necessary and important feature of the Canadian legal landscape. The decision of this court in Stinchcombe (No. I) was a desirable evolution in the law, and one which, for the most part, encouraged a fairer system for accused persons. It also inspired a spirit of openness in the law, which 1 believe has played a large part in advancing the search for truth in criminal trials."

[1999] S.J. No. 408 (Prov. Ct.), online: QL (SJ). 
criminal justice is to be marked by a search for truth, then disclosure and discovery of relevant materials, rather than suppression, must be the starting point." ${ }^{27}$

These examples show that the search for truth is used as a philosophical justification for achieving the desired outcome as a matter of policy in each context. It is used to justify why an accused should not have access to information (because the search for truth may be distorted), and also to justify why an accused should have access to information (because the search for truth is advanced by the disclosure of information). Alan Dershowitz has noted that the search for truth was used in a similar way in the O.J. Simpson trial:

Where it was in their interest to have the jury hear evidence that would hurt Simpson - such as the details of arguments between him and his former wife - the prosecutors argued that the search for truth required the inclusion of such evidence, despite its marginal relevance. On other occasions, they argued that the search for truth required the exclusion of evidence that demonstrated that one of their key witnesses, Los Angeles Police Detective Mark Fuhrman, had not told the truth at the trial. ${ }^{48}$

At a basic philosophical level, there is an inherent contradiction in using the search for truth in both ways. If there is only one "truth" in any given case, the search for it cannot be enhanced by both restricting and facilitating an accused's access to information. Reconciliation of this contradiction is difficult in light of traditional jurisprudence and the absence of clear articulation of the concept in modern cases.

\section{B. EVIDENCE}

The search for truth is also used as a justification to both limit evidentiary and procedural protections that are available to an accused (to his or her detriment), and to protect an accused from trial unfairness (to his or her benefit). The point is made clearly in R. v. P.D.B.: ${ }^{49}$

Unquestionably, what makes the criminal process just, has much to do with fairness of its procedure. If procedural rules are not properly respected, the system could not function. Equally, if procedural rules acquire excess veneration and needlessly preclude a search for the truth, the system will be rendered dysfunctional. ${ }^{\text {so }}$

lbid. at para. 10.

A. Dershowitz, Reasonable Doubts: The O.J. Simpson Case and the Criminal Justice System (New York: Simon \& Schuster, 1996) at 35 [emphasis in original]. The author also notes that the term "search for truth" was invoked by both sides of the Simpson case more than seventy times.

[1994] Y.J. No. 7 (T.C.), online: QL (YJ). The impact of the search for truth on the rules of evidence was the subject of this telling passage by the Supreme Court in $R$. v. Levogiannis, [1993] 4 S.C.R. 475 at para. 22: "One must recall that rules of evidence are not cast in stone. nor are they enacted in a vacuum. They evolve with time. As discussed at length in L.(D.O.), supra, the recent trend in courts has been to remove barriers to the truth-seeking process ... by relaxing certain rules of evidence, such as the hearsay rules, the use of videotaped evidence and out of court statements, have been a genuine attempt to bring the relevant and probative evidence before the trier of fact in order to foster the search for truth."

Ibid. at para 15 . 
There are several areas where the search for truth is used to limit evidentiary and procedural protections for an accused so that the rules do not "needlessly preclude" a search for the truth. For example, it has been used as a justification for the abrogation of the doctrine of recent complaint in sexual assault cases. In $R$. v. Batte, ${ }^{51}$ the Ontario Court of Appeal held that by removing this doctrine, "Parliament sought to dispel an assumption which had a real potential to mislead the trier of fact and distort the search for truth," and that the abrogation of this rule "struck a blow for both equality and the truth-finding function of the criminal trial process." 52

Similarly, the search for truth has also been used to justify disclosure of what would otherwise be privileged communications between a doctor and patient. In $R$. v. Mirkhandan, ${ }^{53}$ a first-degree murder case, the Court held that "[t]he detection and prosecution of the most serious crimes in the Criminal Code outweighs the injury that would be caused by the disclosure of the communication in the court's search for truth in the criminal process." ${ }^{\prime 4}$

The search for truth has also been used to justify not calling certain witnesses, ${ }^{55}$ to support the legislative scheme governing DNA warrants, ${ }^{56}$ to justify the reception of confessions into evidence, ${ }^{57}$ to justify reading the warrant provisions of the Criminal Code widely; ${ }^{58}$ to restrict the application of the doctrine of spousal privilege $;^{59}$ and

(2000), 145 C.C.C. (3d) 449, 34 C.R. (5th) 197 [cited to C.C.C.].

lbid. at para 146.

[1999] O.J. No. 3215 (Ct. Just.), online: QL (OJ).

lbid. at para. 24.

R. v. Brown, [1999] O.J. No. 4873 at paras. 15, 16 (S.C.), online: QL (OJ). "The truth-seeking capacity of the trial will not likely be adversely affected by the absence of these witnesses. Accordingly, I am not satisfied the search for the truth or the interests of justice require the calling of these witnesses by the Court."

R. v. F.(S.) (2000), 141 C.C.C. (3d) 225 (Ont. C.A.). In that case, the Court quoted with approval the trial judge's reasons for upholding the DNA warrant legislation at 240: "In Hill J.'s reasons, he properly charged himself that a determination as to reasonableness under $\mathrm{s}$. 8 required a balancing of the individual interests of bodily integrity, dignity and privacy against the societal interests in effective law enforcement and the furtherance of truth-seeking in the criminal process.... The important government justifications of fostering effective crime control, protecting the innocent, enforcing society's criminal laws, and substantially improving the search for truth in the criminal trial process warrant the court-authorized intrusion upon bodily integrity."

s7 $R$. v. Thornton (1999), 180 N.S.R. (2d) 23 (S.C.). In that case, the Court quoted the Supreme Court decision in $R$. v. Smith (1989), 50 C.C.C. (3d) 308 at 324 (S.C.C.): "Confessions are amongst the most useful types of evidence. Where freely and voluntarily given, an admission of guilt provides a reliable tool in the elucidation of crime, thereby furthering the judicial search for the truth and serving the societal interest in repressing crime through the conviction of the guilty."

CanadianOxy Chemicals Ltd. v. Canada (Attorney General) (1999), 133 C.C.C. (3d) 426 at para. 27 (S.C.C.) [reference omitted]: "In order to be fair, the criminal process must "enable the trier of fact to "get at the truth and properly and fairly dispose of the case" while at the same time providing the accused with the opportunity to make a full defence'... This reciprocal fairness demands that the Crown be able to fairly seek and obtain evidence rebutting the accused's defences. If the respondents' submission on the interpretation of s. 487(1) were accepted, a search warrant would never be available for this purpose. This narrow interpretation would frustrate the basic imperative of trial fairness and the search for truth in the criminal process." See also $R$. v. Rayworth, [1999] O.J. No. 5289 (Ct. Just.), online: QL (OJ). 
to justify late disclosure of expert reports by the Crown. ${ }^{60}$

In each of these examples, courts are limiting evidentiary and procedural protections for an accused by invoking the need to facilitate the search for truth. As in the disclosure context, no real insight is offered on a philosophical or theoretical level as to what it means to say that these policy decisions are necessary to advance the search for truth; the phrase is simply stated as a fact that justifies the decision in the circumstances of each particular case.

At the same time, the search for truth has also been used to justify protecting an accused from unfairness in the course of a trial. In $R$. v. Kane,$^{61}$ the Court held that:

The interests of justice demand a search for the truth. Where the truth is deliberately put aside for expediency's sake, the proceedings become unfair. The standard of proof must be the same for every accused irrespective of who he is or to what group he belongs. ${ }^{62}$

Similarly, in $R$. v. Quitte ${ }^{63}$ the Court noted that "if the purpose of a criminal trial is the search for truth ... then the fundamental requirement of fairness means that there must be faimess to the complainant and witnesses as well as fairness to the accused." 64

Again, there is an inherent contradiction in using the search for truth to limit evidentiary and procedural protections for an accused (by tilting the "fairness" balance in favour of the prosecution), and at the same time by using it to require strict adherence to the standard of proof beyond a reasonable doubt (thereby tilting the

R. v. Edelenbos, [2000] O.J. No. 2147 (S.C.), online: QL (OJ). In that case, the defence argued that the Crown should not be permitted to call the accused's common-law spouse with whom the accused had cohabited for a period of seventeen years and had three children, on the grounds that she should be included in the class of individuals who are incompetent to testify based on the common-law rule of spousal incompetency. In dismissing the defence argument, the Court commented at para. 7: "I have no reason to doubt the Crown's submission that, if successful, this alteration could double the pool of individuals who are incompetent to participate in the court's search for the truth."

$R$ v. Beamish (1996), 144 Nfld. \& P.E.I.R. 352 (P.E.I. S.C.) at para. 2: "The Crown says it delivered the report immediately upon receiving it from the Laboratory, which was immediately after it was considered final, and that there is no prejudice in any event on the defence because all it does is indicate that the evidence is even stronger in the sense that the estimated frequency of occurrence is higher in all cases, and that, in its search [for] the truth, the jury should have the best evidence."

61 (1998), 174 N.S.R. (2d) 14 (S.C.).

62 Ibid. at para. 47. See also R. v. Elliott (1999), 105 O.T.C. 241 (S.C.). A contrary view is presented in W.T. Pizzi, Trials Without Truth: Why Our System of Criminal Trials Has Become an Expensive Failure and What We Need to Do to Rebuild It (New York: New York University Press, 1999) at 71-72. Pizzi maintains that legal institutions - primarily courts - are far too concerned about the rights of suspects and defendants. He claims that the strong emphasis on the rights of suspects and defendants and other fairness considerations have resulted in the establishment and elaboration of rules and procedural safeguards that function as barriers to truth. 
"fairness" balance in favour of the accused). If there is only one "truth" in any given case, the search for it cannot be enhanced by doing both.

\section{Conclusion}

As these two criticisms illustrate, it is difficult to support the idea that a criminal trial is a search for truth when there has been very little judicial consideration of what the phrase means. This concept is contrary to traditional jurisprudence that sees a criminal trial as a systematic evaluation of evidence, and the cases do not assist in revealing the development of this idea or of an incremental shift from the traditional view. The absence of an identifiable beginning of the concept makes it even more elusive.

Perhaps the most significant problem with the way that courts are using the concept is a reflection of the fundamental failure to consider whether a trial judge, presiding over the fate of a real person, and relying on real witnesses with all of their frailties, can ever presume to be able to determine the truth about what happened. If it is accepted that the truth can never be found, the entire notion that a criminal trial is a search for truth becomes suspect.

The better view is that a criminal trial is nothing more than a systematic testing of evidence to the required legal standard, and that it has nothing to do with the truth. This view is supported by the traditional position, and does not import the very uncertain and ill-defined concept of truth into judicial decision-making. Judges should evaluate the evidence as it is presented, and not deign to search for truth. By searching for truth, judges might miss the point of a criminal trial: to determine whether an accused is guilty beyond a reasonable doubt. 